УДК 349.3

DOI https://doi.org/10.17308/vsu.proc.law.2021.3/3541

\title{
ДОРЕВОЛЮЦИОННЫЙ ПЕРИОД РАЗВИТИЯ СОЦИАЛЬНОЙ ЗАЩИТЫ В РОССИИ (XVI-XVIII ВВ.)
}

\author{
А. Ю. Гусев, М. Р. Яхина \\ Национальный исследовательский университет \\ "Высшая школа эконолики" \\ Поступила в редакцию 23 января 2021 г.
}

\begin{abstract}
Аннотация: подвергаются анализу основные источники законодательства, отражавшего вопросы социальной защиты в России в XVI-XVIII вв., высказаны отдельные предложения о заилствовании положительного опыта законодательного регулирования для совреленного российского законодателя, сделан вывод о тол, что соииальное обеспечение со стороны государства в России анализируелого периода сводилось преилущественно $\kappa$ борьбе с бедностью.
\end{abstract}

Ключевые слова: общественное призрение, благотворительность, борьба с бедностью, Соборное уложение 1649 г., Петр I, Екатерина II.

\begin{abstract}
: the authors analyzed the main sources of legislation, reflecting the issues of social protection in Russia in XVI-XVIII centuries, made separate proposals to adopt positive experience of legal regulation in modern Russian legislator, concluded that social security from the state in Russia in the analyzed period was limited mainly to the fight against poverty.

Key words: public charity, charity, the fight against poverty, the Cathedral Code of 1649, Peter I, Catherine II.
\end{abstract}

История чуть ли не на каждой странице говорит, что бедность неразлучна с человечеством, она сопровождала его на всех стадиях исторического развития ${ }^{1}$.

Анализ исторических аспектов вопросов сощиальной защиты, защиты права в области социального обеспечения, в частности ее негативного опыта, обнажает ошибки в социальной политике государства, позволяет выявить особенности развития социальной защиты в России на разных этапах ее развития, спрогнозировать развитие и возможные проблемы законодательного регулирования в будущем.

Вопросы социальной защиты и социального обеспечения граждан решались Российским государством в разные эпохи по-разному, равно как и степень социальной защиты, инструменты такой защиты были различны.

Законодательное регулирование указанных вопросов на рассматриваемом этапе отличались бессистемностью, противоречивостью, фрагментарностью, продолжая оставаться таковым до настоящего времени.

Несмотря на то что официальное научное обоснование самостоятельности права социального обеспечения как отрасли в общей системе права

${ }^{1}$ См.: Преображенский В. О благотворительности. Красноярск, 1898. С. 1.

(C) Гусев А. Ю., Яхина М. Р., 2021 
впервые прозвучали на состоявшемся в 1966 г. в Праге симпозиуме по социальному обеспечению, на котором присутствовали ученые из стран так называемого социалистического лагеря, в том числе и профессор В. С. Андреев ${ }^{2}$, вопросы социального обеспечения (благотворительность, призрение) в разной степени были урегулированы правом, это касается и дореволюционного периода становления в России.

Первой кодификацией русских законов стало Соборное уложение 1649 г., которое обобщило и систематизировало значительное число законодательных актов, регулировавших различные сферы жизни русского общества, разобщенных и нередко противоречащих друг другу. Это важный правовой документ того времени, содержавший 25 глав и 967 статей.

Соборное уложение 1649 г. определенным образом упрощало систему российского законодательства, обеспечивало относительную стабильность законов. Одновременно Соборное уложение закрепило крепостное право в России, при котором крестьянин становился собственностью помещика, а последний отвечал за его обеспечение.

Принятию Уложения предшествовали такие социальные причины, как увеличение поборов и налогов (со стороны государства), цен на товары, голод. Непосредственным поводом для его принятия послужило вспыхнувшее восстание посадского люда в 1648 г., они обращались к царю с челобитными об улучшении своего материального положения, о защите от постоянных притеснений.

В Соборном уложении 1649 г. просматривались отдельные правовые отрасли, среди которых выделялось уголовное, гражданское, семейное право.

Из социальных вопросов, которые регулировались в Соборном уложении 1649 г., следует выделить введение государственного сбора за выкуп людей, попавших в плен. Размер такого денежного сбора варьировался в зависимости от сословной принадлежности. Так, за дворян и за детей боярских, московских стрельцов он был в два раза выше, чем за пашенных крестьян (ст. 1, глава 8 Соборного уложения 1649 г.).

Призрение в России можно разделить на общественное (направлено на поддержку всеми представителями общества), государственное (опека, забота о нуждающихся, оказываемая органами государства), призрение церковью.

Последний вид опеки в период правления царя Алексея Михайловича получило развитие в связи с учреждением Монастырского приказа (отвечал за строение богаделен, домов для бедных, вдов, престарелых и сирот), в 1670 г. учреждается особый Приказ строения богаделен ${ }^{3}$, а после 1677 г. богадельни находились ведении Приказа Большого Дворца ${ }^{4}$

2 См.: Право социального обеспечения : учеб. для бакалавров / отв. ред. Э. Г. Тучкова. М., 2016. С. 31.

${ }^{3}$ См.: Георгиевский П. И. Призрение бедных и благотворительность. СПб., 1894. C. 15 .

${ }^{4}$ См.: Галай Ю. Г., Черных К. В. Нищенство и бродяжничество в дореволюционной России : законодательные и практические проблемы. Н. Новгород, 2012. 
По Соборному уложении 1649 г. любое право могло быть защищено в суде, судебному процессу была посвящена отдельная Х глава Соборного уложения ${ }^{5}$.

Так, согласно ст. 1 Соборного уложения: «Суд государя царя и великого князя Алексея Михайловича всея Руси, судити бояром и околничим и думным людем и дияком, и всяким приказным людем, и судьям, и всякая росправа делати всем людем Московского государства, от большего и до меньшего чину, вправду. Также и приезжих иноземцов, и всяких прибылых людей, которые в Московском государстве будут, тем же судом судити и росправа делати по государеву указу вправду, а своим вымыслом в судных делах по дружбе и по недружбе ничего не прибавливати, ни убавливати, и ни в чем другу не дружити, а недругу не мъстити и никому ни в чем ни для чего не норовити, делати всякие государевы дела, не стыдятся лица сильных, и избавляли обидящаго от руки неправеднаго».

Необходимо отметить, что лишь представители высшего сословия могли обратиться в суд. Помещичьи крестьяне были лишены права представительствовать в суде по имущественным спорам, в связи с чем приходится констатировать полную социальную незащищенность отдельно взятых слоев населения.

В 1682 г. указом царя Федора Алексеевича, который предписывал «произвести строительство двух богаделен и осуществить разборку московских нищих», были установлены меры по борьбе с нищенством, которые были, с одной стороны, направлены на выявление действительно нуждающихся неимущих лиц (убогих, престарелых, больных) и оказание им помощи, а с другой - носили репрессивный характер: в отношении профессиональных нищих (притворные воры и всем здоровы, и работать могут) применялись исправительные работы. Созидательное начало по данному указу усматривалось в том, что данным документом предписывалось учить грамоте детей нищих ${ }^{6}$.

Несовершенство системы социальной защиты, выражавшееся в тот период в бессистемности ее функционирования, влияло на появление таких негативных явлений в политической жизни государства, как Соляной бунт в Москве (1646 г.), Медный бунт в Москве (1662 г.), мятеж под предводительством С. Разина (1670-1671 гг.), что требовало исправления государственного подхода к решению существующих социальных проблем.

Период правления царя и императора Петра I характеризуется глобальными реформами всей государственной системы, которые затронули

С. 22 ; Владилирский-Буданов М. Ф. Обзор истории русского права. СПб., 1886. C. 234.

5 См.: Официальный сайт Российской государственной библиотеки. URL: https://dlib.rsl.ru/ (дата обращения: 24.07.2020).

${ }^{6}$ См.: Ширяева C. В. Генезис социальной помощи в России (с момента появления христианства до рубежа XVIII-XIX вв.). URL: https://cyberlenika.ru/ (дата обращения: 24.07.2020). 
и социальную политику России. Можно констатировать, что при Петре I были заложены основы государственного общественного призрения.

За период правления Петра I вышло около 20 указов, направленных на искоренение нищенства в России ${ }^{7}$.

30 ноября 1691 г. вступил в силу Указ Петра I «О забирании нищих, притворяющихся увечными и наказании их». Такую категорию нищих, которая именовалась «ленивыми прошаками», было указано бить кнутами и батогами и направлять к месту их жительства. Если приведенные меры «действия не возымели», вновь возвращавшихся к нищенскому промыслу ссылали на каторжные работы. При Петре I здоровые нищие разделялись на мужчин и женщин, в отношении таких лиц проводилась политика принуждения к труду: здоровые мужчины направлялись в «Смирительные дома», а женщины - в прядильные дома, которые именовались «шпингаузами».

Указом Петра I от 31 января 1712 г. был установлен запрет на подачу милостыни. Император называл «вредными для государства» людей, которые подают милостыню. Тем, кто дает подаяние, полагался штрафр в 5 руб., за повторный проступок - штраф удваивался ${ }^{8}$.

Борьба против нищенства проводилась не только путем применения репрессий к нищим, но и путем предоставления социальной (государственной) помощи различным категориям нищих: строились больницы, дома призрения, сиротские дома. Неспособные к труду помещались в госпитали, богадельни, дома призрения. Престарелым и инвалидам из казны выдавались «кормовые деньги» (разовая денежная помощь) для обеспечения жильем и пищей. Купцы и бояре должны были вкладывать «милостные» средства в богадельни и госпитали ${ }^{9}$.

В период правления Петра I, проводившего активную внешнюю военную политику, выделяется отдельная категория нуждающихся - лица, получившие увечья в период военных действий. В эту категорию вошли: военные инвалиды; воины, получившие травмы в военный период.

Государство особо заботилось об этой категории. В петровские времена старых солдат, не способных к строевой военной службе вследствие заболевания, ранения или увечья, а также из-за преклонного возраста, стали называть инвалидами, направляя их для «дослуживания» на штатские должности. Для увечных воинов, престарелых солдат, которые не могли сами себя содержать, Петр I организовывал строительство госпиталей. Призрение о таких воинах осуществляли также монастыри, куда те направлялись для проживания и питания. В изданном в 1712 г. Указе «Об учинении во всех губерниях гошпиталей» устанавливалось, что «...для самых увечных, таких, которые ничем работать не смогут, ни стеречь,

${ }^{7}$ См.: Годунский Ю. Откуда есть пошла благотворительность на Руси // Наука и жизнь. 2019. 3 марта. С. 34.

${ }^{8}$ См.: Павлова О. К. Политика общественного призрения и благотворительности в царствование Петра I. URL: https://philosophy.spbu.ru/ (дата обращения: 24.07.2020).

${ }^{9}$ См.: Там же. 
также зело престарелым учинить гошпитали...». В Москве было построено 90 подобных заведений, в которых содержалось около 4000 человек ${ }^{10}$.

Забота о нуждающихся в городах была возложена на губернские и городские магистраты, в деревнях такую заботу должны были осуществлять помещики, в свободных землях - старосты и сотские.

До правления Петра I благотворительность и призрение нищих были сосредоточены преимущественно в руках церкви. В период правления Петра I сфера общественного призрения стала делом государства.

Делом общественного призрения занимались вначале правления Петра I Патриарший и Монастырский приказы, с 1721 г. - Святейший синод, а в 1724 г. - Камер-контора, которая представляла собой финансовое ведомство ${ }^{11}$.

Государственные контрольно-надзорные фрункции за указанными государственными учреждениями были закреплены в период правления Петра I за фискалами. Указом от 17 марта 1714 г. «О должности фискалов» ${ }^{12}$ были установлены полномочия фискалов, а также процессуальные средства их деятельности.

Таким образом, будущим императором впервые в России был создан орган, специально предназначенный для контроля и надзора за соблюдением законов. В основные обязанности фискалов входило: тайно следить за неправильным судопроизводством и осуществлять надзор за соблюдением законов. Фискал должен был обнаруживать нарушения закона. Деятельность фискалов была направлена также на борьбу с хищениями государственных денежных средств, в том числе выделяемых на работу созданных приказов, ведавших делом общественного призрения. Фискалы могли проводить проверки расходования денежных средств и о выявленных нарушениях докладывать представителям высшей власти. Становление фискалата проходило трудно и медленно. Этот институт сразу вызвал неприятие всей чиновничьей иерархии и держался он только благодаря поддержке царя. Впоследствии институт фискалов был преобразован в прокуратуру ${ }^{13}$.

12 января 1722 г. Петром I издан указ о реорганизации Сената, в котором были учреждены должности прокуроров в надворных судах. При Сенате учреждались должности генерал-прокурора и обер-прокурора, в каждой коллегии работали прокуроры, подчиненные генерал-прокурору.

Изначально прокурор уполномочивался быть «оком государевым», т. е. представителем высшей власти. Ему предписывалось следить за исполнением законов и указов.

${ }^{10}$ См.: Баринова Г. В. Должны служить пожизненным и тихим для раненых воинов пристанищем // Военно-исторический журнал. 2015. № 9. С. 55-61.

${ }^{11}$ См.: Павлова О. К. Указ. соч.

${ }^{12}$ URL: https:/constitution.garant.ru/ (дата обращения: 24.07.2020).

${ }^{13}$ См.: О должности фискалов : указ о должности // Официальный сайт «Президентская библиотека имени Б. Н. Ельцина». URL: https: //prlib.ru/ (дата обращения: 23.07.2020). 
27 апреля 1722 г. издан Указ «О должности генерал-прокурора», в котором определялись должностные обязанности и полномочия прокурора, в частности генерал-прокурор должен был осуществлять надзор за Сенатом. В указе закреплялось: «...дабы Сенат в своем звании праведно и нелицемерно поступал. А ежели что увидит противное сему, тогда в тот же час повинен предлагать Сенату явно, с полным изъяснением, в чем они или некоторые из них не так делают, как надлежит, дабы исправили. А ежели не послушают, то должен в тот же час протестовать и оное дело остановить. И немедленно доносить нам, если весьма нужное». Указ предписывал генерал-прокурору «смотреть над всеми прокурорами, дабы в своем звании истинно и ревностно поступали... Генерал и обер-прокуроры ничьему суду не подлежат, кроме суда императора» ${ }^{14}$.

Главной фрункцией прокуроров был надзор за деятельностью тех учреждений, при которых они состоят. Надзор осуществлялся в фрорме напоминания о необходимости строго следовать регламентам и указам, а также в фрорме проверки исполнения принятых решений и опротестования незаконных решений.

Результатом деятельности фрискалов и прокуроров при Петре I стало снижение фрактов злоупотреблений со стороны чиновников, казнокрадства, коррупции.

Нарушенное право в период правления Петра I могло быть защищено путем обращения в судебные органы.

Императором была проведена судебная редорма, которая знаменовала собой издание двух указов Петра I:

- Устав 1715 г. «Краткое изображение процессов и тяжб» (которым допускалось и состязательное производство в гражданских делах, разрешалось ведение дела адвокатами);

- Указ 1723 г. «О фороме суда», который наметил поворот к состязательной форме судебного процесса. В судах разрешалось судебное представительство при разборе любых гражданских дел на основании доверенности или поручительства. Приведенные указы императора не устанавливали каких-либо категорий гражданских дел, в частности возникавшие социальные споры (к примеру, о выплате пенсионного обеспечения увечному солдату), исходя из положений указов, могли быть разрешены судебными органами.

Таким образом, государством в период правления Петра I была проведена значительная работа в области социальной защиты (общественного призрения) граждан и противодействия нищенству в России: были заложены основы государственного общественного призрения, эта сфера перешла от церкви в ведение государства и попала под надзор государственных органов: вначале фискалов, затем - прокуроров; в связи с нарушенным правом можно было обратиться в судебные органы. Следует констатировать, что государство, по сути, полностью взяло на себя бремя обеспечения защиты социальных прав населения.

${ }^{14}$ URL: https://hist.msu.ru (дата обращения: 23.07.2020). 
Основы государственной системы общественного призрения, заложенные в период правления Петра I, получили законодательное закрепление в период правления Екатерины II.

Важным законодательным актом императрицы стал вышедший 7 ноября 1775 г. Указ «Учреждения для управления губерний Российской империи» ${ }^{15}$.

В соответствии с данным указам в 1775-1785 гг. была проведена кардинальная реформа административно-территориального деления Российской империи. Задачей губернской реформы 1775 г. было укрепление власти дворянства на местах с целью предотвращения крестьянских восстаний, целью реформы было приспособление нового административного аппарата к фискальным и полицейским делам ${ }^{16}$, что подчеркивает решение социальных вопросов императрицей Екатериной II прежде всего «жесткими», «полицейскими» мерами.

Данным указом была установлена двухуровневая система социальной помощи нуждающимся: приказы общественного призрения и местные органы попечительства сословного характера (дворянская опека, сиротский суд). Приказы общественного призрения были созданы в 40 из 55 губерний. По мнению Екатерины II, все отрасли государственного управления, кроме политических, должны заключаться в провинциях, где местные учреждения были основаны на сословном самоуправлении ${ }^{17}$.

В провинции были созданы приказы общественного призрения под предводительством губернатора с участием в их руководстве зажиточных горожан от разных сословий. Приказы должны были следить за функционированием народных школ, больниц, богаделен, сиротских домов, а также учреждений для душевнобольных, смирительных и работных домов, что свидетельствует о системном подходе при организации приказов «благотворительности»: в них были аккумулированы основные виды благотворительности того времени.

Надзорные полномочия за сложившейся государственной системой призрения были возложены на генерал-прокурора и подчиненных ему прокуроров. При Екатерине II объем полномочий генерал-прокурора и подчиненных ему прокуроров по сравнению с петровскими временами значительно увеличился.

Защитные механизмы контроля за управлением системной социальной защиты населения в Российском государстве, расходования выделяемых финансов, в том числе на нужды призрения, были возложены на прокуратуру. Прокуроры, осуществляя надзорные полномочия за приказами общественного призрения, могли как проверять, так и опротестовывать принятые их должностными лицами решения.

${ }_{15}$ URL: https://constitution.garant.ru/ (дата обращения: 23.07.2020).

16 См.: Губернская реформа 1775 г. // Президентская библиотека имени Б. Н. Ельцина. URL: https://prlib.ru/ (дата обращения: 23.07.2020).

17 См.: Владилирский-Буданов М. Ф. Обзор истории русского права. Ростов н/Д., 1995. С. 267. 
В период правления Екатерины II граждане разных сословий, за исключением крепостных, могли защищать свои права путем обращения в суд ${ }^{18}$.

При Екатерине II в России была создана система судов, отделенная от исполнительной власти, был введен сословный принцип судоустройства: для дворян в каждом уезде создавался уездный суд, апелляционной инстанцией для уездных судов являлся верхний земский суд, состоявший из двух департаментов - по уголовным и гражданским делам; для горожан первой судебной инстанцией являлись городские магистраты, апелляционной инстанцией выступали губернские магистраты, государственные крестьяне могли обратиться в уездную нижнюю расправу. Апелляционной инстанцией для нижней расправы являлась верхняя расправа. Действовали совестные суды для дворян - по дворянским делам, горожан по делам горожан, крестьян - по крестьянским делам. Такой суд носил характер примирительного и рассматривал гражданские иски.

Статья 395 главы 26 «Учреждение для управления губерний» от 7 ноября 1775 г. устанавливала компетенцию совестных судов: «Понеже личная безопасность каждого верноподданного весьма драгоценна есть человеколюбивому Монаршему сердщу; и для того, дабы подать руку помощи страждущим иногда более по несчастливому какому ни есть приключению, либо по стечению различных обстоятельств, отягчающих судьбу его выше мер им содеянного, заблагорассуждается учредить... в каждом наместничестве по одному суду под названием: совестный суд» ${ }^{19}$.

Совестные суды могли рассматривать споры по социальным вопросам, поскольку нормативного закрепления определенных категорий дел установлено не было. К примеру, требовать назначения содержания мог увечный солдат.

Указом императрицы 1775 г. «Учреждение для управления губерний Российской империи» ${ }^{20}$ государство устанавливает закрепление принудительного труда и трудового принуждения для нищих. С даты издания указа создаются работные дома для праздношатающихся и занимающихся нищенским промыслом. Для «буйных ленивцев» и лиц «непотребного и невоздержанного жития», т. е. «профессиональных» нищих, законодательными актами учреждаются смирительные дома, содержание в которых представляло собой тюремный режим.

При Екатерине II в 1764 г. впервые в Москве, а в 1770 г. в Санкт-Петербурге были открыты воспитательные дома с госпиталем для рожениц, на территории империи начали строиться воспитательные дома для детей-сирот и зазорных (незаконнорожденных) младенцев. В воспитательных домах содержались дети, рожденные вне брака, подкидыши, дети, оставляемые в таких домах в связи с бедностью. В таких домах дети сна-

${ }^{18}$ См.: Исаев И. А. История государства и права России : учебник. 2-е изд., перераб. и доп. М., 2001. С. 298.

${ }^{19}$ Российское законодательство X-XX веков. М., 1987. Т. 5. С. 274.

${ }^{20}$ Полн. собр. законов Российской империи. СПб., 1830. Собр. 1. Т. 20. 


\section{Вестник ВГУ. Серия: Право}

чала получали общее образование, а затем в возрасте 15 лет детей отдавали на обучение ремеслам.

Открывались сиротские дома - учебные заведения для детей малоимущих родителей из таких сословий, как купцы, чиновники, канцелярские служащие. Подобные дома принимали детей обоего пола в возрасте с 7 до 11 лет. По окончании обучения в сиротских домах выпускников направляли на службу в государственные учреждения, фрабрики, заводы, для обучения к ремесленникам, торговцам, работникам иных специальностей.

В Москве появились первые всесословные больницы для бедных: в 1764 г. - Павловская, а в 1776 г. - Екатерининская.

При Екатерине II военные инвалиды стали обеспечиваться пенсиями. Отдельным военным инвалидам было назначено денежное содержание: армейским полковникам - 120 рублей в год, нижним чинам - до 10 рублей. С 1764 г. за 35-летнюю службу военным ветеранам выплачивали половину ранее получаемого им жалованья ${ }^{21}$. Тем самым следует констатировать, что впервые в российском законодательстве были урегулированы вопросы пенсионного обеспечения военнослужащих.

Если в петровские времена повинность содержания уволенных с военной службы солдат распространялась на все монастыри, то по Указу Екатерины II от 26 февраля 1764 г. «О секуляризации монастырских землевладений» ${ }^{22}$ увечные воины переводились из монастырей в особые инвалидные команды, созданные в военных гарнизонах более чем в 30 городах России. Кроме инвалидных команд, при внутренних гарнизонах создавались инвалидные роты, офицеры и солдаты из которых несли нестроевую службу в качестве часовых у складов, школ и других объектов. При Екатерине Великой получило дальнейшее развитие строительство инвалидных домов - военных богаделен для призрения раненых, больных и престарелых воинов.

7 февраля 1774 г. вступил в силу указ, который касался дальнейшей жизни отставных воинских чинов. В данном законодательном документе предписывалось воинам, которые ушли в отставку (или которые не способны больше к воинской службе), «определять пропитание» из ведомства главной Военной канцелярии ${ }^{23}$. В 1780-х гг. стали создаваться специальные «Инвалидные дома» для отставных военнослужащих.

В 1764 г. было основано «Императорское воспитательное общество благородных девиц», позже - Смольный институт. Оно было создано с целью формирования образованного общества, распространения образо-

${ }^{21}$ См.: Гаврилина Н. А. Реформы Екатерины II и их роль в организации общественного призрения // Электронный научный журнал Курского гос. ун-та. 2014. № 3. URL: https://cyberlenika.ru/ (дата обращения: 23.07.2020).

${ }^{22}$ См.: Слолович И. К. Русское монашество : возникновение. Развитие. Сущность (988-1917). М., 1997. С. 283 ; Полн. собр. законов Российской империи. Собр. 1. Т. 16, № 12060 .

${ }^{23}$ См.: Историческое обозрение мер правительства по устройству общественного призрения в России. СПб., 1874. С. 22. 
вания. В начале действия общества будущих воспитанниц отбирали из дворян, но спустя год после открытия Общества было открыто отделение для остальных сословий (не принимались в Общество лишь дети крепостных крестьян).

Приказы общественного попечения представляли собой «центральный» уровень общественной благотворительности, на местах делами милосердия занимались поместные органы попечения: суд для сирот, дворянская опека. В период правления Екатерины II на сельские и городские общины и приходы была возложена обязанность «прокармливать своих бедных, не допускать их до нищеты» ${ }^{24}$.

В период правления императрицы получила развитие система благотворительности - меценатство, которое стало носить системный характер. На взносы меценатов строились благотворительные учреждения, содержание получали воспитательные, сиротские дома, больницы, иные объекты, оказывающие благотворительную помощь.

Как верно указывает известный дореволюционный экономист проdpeccop Е. Д. Максимов, учрежденные Екатериной II приказы общественного призрения соединяли бюрократические и общественные начала. Проводились кредитные операции, которые давали возможность этим органам приобрести материальную независимость. Однако это требовало времени, а для нужд призрения его оставалось недостаточно. Екатерине II удалось создать систему призрения России и сделать ее необходимой принадлежностью государства и общества ${ }^{25}$.

В период правления Павла I, в целом, государственная система общественного призрения, заложенная при Екатерине II, продолжала функционировать, получили развитие благотворительные и учебные учреждения.

Так, по Указу Павла I от 12 ноября 1796 г. его супруга Мария Федоровна стала «начальствовать над воспитательным обществом благородных девиц», несколько позже император назначил супругу «главной начальницей воспитательных детских домов Петербурга и Москвы» (указ от 2 мая 1797 г.). Позже в ведение канцелярии, Ведомства учреждений императрицы Марии, перейдут лечебницы, сумасшедшие дома, приюты и богадельни и иные благотворительные учреждения ${ }^{26}$.

Заботясь об устройстве уже существующих, Мария Федоровна открывала и новые благотворительные и учебные заведения.

Система государственного общественного призрения, созданная Екатериной II, просуществовала с незначительными изменениями вплоть до введения земских учреждений в 1864 г.

${ }^{24}$ Годунский Ю. Указ. соч. С. 54.

${ }^{25}$ См.: Максилов Е. Д. Приказы общественного призрения (в их прошлом и настоящем) // Трудовая помощь. 1901. № 9. С. 540.

${ }^{26}$ См.: Лозовская Е. Г., Харинина Л. В. Благотворительная деятельность ведомства учреждений императрицы Марии Федоровны // Вестник ВолГУ. Серия 7. 2007. Вып. 6. С. 136-139. 
19 февраля 1861 г. император Александр II подписал Манифест «О всемилостивейшем даровании крепостным людям прав состояния свободных сельских обывателей» и утвердил Положение о крестьянах, вышедших из крепостной зависимости, которыми устанавливались порядок и условия освобождения крестьян и передачи им земельных наделов. На основании этих законодательных актов крестьяне, до сих пор не обладавшие таковыми, получали личную свободу и право распоряжения своим имуществом, приобретали гражданские права, среди которых были самостоятельное заключение договоров и ведение судебных дел ${ }^{27}$.

В 1864 г. вступает в силу Положение о губернских и уездных земских учреждениях (далее - Положение 1864 г.) ${ }^{28}$, которым система государственного общественного призрения заменяется земскими учреждениями. Положение 1864 г. распространялось на 33 губернии и вводило всесословное выборное местное самоуправление в уездах и губерниях. Таким образом, с 1864 г. на законодательном уровне было закреплено право всех сословий общества, в том числе крестьян, представлять свои интересы в сфере местного самоуправления, где решалось значительное число социальных вопросов.

С этого времени сфера социального обеспечения (общественного призрения) находилась в ведении земств, которые подразделялись на Губернские земские учреждения, представлявшие собой Губернское земское собрание и Губернскую земскую управу, а также Уездные земские учреждения, в которые входило Уездное земское собрание и Уездная земская управа.

Положением о губернских и уездных земских учреждениях (п. 2 главы 1) закреплялись весьма широкие обязанности земств, в том числе заведывание имуществом, капиталами и денежными сборами земств, меры обеспечения народного продовольствия, заведывание земскими благотворительными и прочими мерами призрения, способы прекращения нищенства, участие в попечении о народном образовании и народном здравии. Земские учреждения могли устанавливать сборы на общественное призрение.

Анализ норм Положения 1864 г. свидетельствует о том, что полномочия земств являлись не конкретизированными, что на практике тормозило развитие общественного призрения: в связи с неясностями закона земские учреждения должны были обращаться к высшему правительству для разъяснений положений закона, что приводило к затягиванию во времени разрешения вопросов призрения, а также остается фактом, что земства редко добивались положительного разрешения своих ходатайств ${ }^{29}$.

${ }^{27}$ Полн. собр. законов Российской империи. Т. 36. Отд. 1. СПб., 1863. № 36657 ; Крестьяне // Энциклопедический словарь / под ред. И. Е. Андреевского. СПб., 1895. Т. 16a.

${ }^{28}$ См.: Сайт Тихоокеанского гос. ун-та. URL: https://pnu.edu.ru/ (дата обращения: 23.07.2020).

${ }^{29}$ См.: Гаврилина H. А. Роль земских учреждений в развитии общественного призрения во второй половине XIX века // Вестник Саратовского гос. социальноэкономического ун-та. 2005. № 11. С. 50. 
Несмотря на имевшиеся законодательные пробелы, земские учреждения развивали сферу общественного призрения, тратя значительные денежные средства: в течение 20 лет с начала их учреждения необязательные расходы земских учреждений возросли в 3,3 раза: расходы на народное образование возросли в 4,9 раза; на общественное призрение более чем в 5,5 раз $^{30}$.

В случае несогласия с действиями земских учреждений в области общественного призрения их действия могли быть обжалованы в административном порядке, а также в суд.

Губернскому собранию принадлежало право рассмотрения жалоб, приносимых на действия земских управ, проведение документальных проверок, в том числе истребования личных объяснений от членов управ, проведения местных дознаний (ст. 114, 115 Положения 1864 г.). Отдельные жалобы на постановления Земских собраний рассматривались в Правительствующем сенате (ст. 118 Положения 1864 г.).

Надзорная деятельность прокуроров сводилась к надзору за должностными лицами судебного ведомства, не могли осуществлять надзор за министерствами и создаваемыми ими органами власти на местах.

В случае нарушения прав действиями земских учреждений заинтересованные лица могли обратиться в суд. Статья 119 Положения 1864 г. устанавливала, что «частные лица, общества и установления в случае нарушения их гражданских прав действиями земских учреждений имеют право иска на общем основании» ${ }^{31}$.

В 1892 г. был издан Устав об общественном призрении (далее - Устав 1892 г. $)^{32}$. Это был своего рода кодекс, включающий в себя законодательные акты второй и даже первой половины XVIII в.

Уставом 1892 г. устанавливалась следующая организация призрения: высшее заведование принадлежало Министерству внутренних дел. Губернские земские собрания наблюдали на местах за деятельностью приказов призрения, осуществляемой земскими и городскими учреждениями, сословными обществами и частными лицами, а также руководили ими для дальнейшего принятия мер в случае превышения выделенных расходов. Сохранялся сословный принцип призрения.

Произошло упрощение процедуры открытия благотворительных организаций, утверждался примерный устав для обществ, преследующих «общеблаготворительные цели»: такие общества могли открываться с разрешения губернаторов либо градоначальников.

Устав определял источники доходов на дело общественного призрения и как эти доходы должны распределяться.

${ }^{30}$ См.: Там же. С. 58.

${ }^{31}$ См.: Сайт Тихоокеанского гос. ун-та. URL: https://pnu.edu.ru/ (дата обращения: 23.07.2020).

32 См.: Сайт государственной публичной исторической библиотеки. URL: https://elib.shpl.ru/ (дата обращения: 23.07.2020). 
Основные виды благотворительной помощи бедным: снабжение одеждой, пищей, жильем, выдача денежных пособий, трудоустройство, оказание бесплатной медицинской помощи, помощь в воспитании сирот, определение в приюты, богодельни.

Общества, получив разрешения властей, могли открывать благотворительные заведения: общественные дома, приюты, дома трудолюбия, больницы, амбулатории и другие учреждения.

Проведенный анализ исследованного российского законодательства в дореволюционной России показывает, что социальная защита, социальное обеспечение со стороны государства сводилось к борьбе с бедностью (что имеет место и в настоящее время) ${ }^{33}$. Глубинную причину бедности следует искать в әкономическом неравенстве работодателей и нанимателей, помещиков и крестьян, правящих элит и низших слоев общества, что, как верно указывают исследователи, приводило к волевому неравенству, в котором главная роль отводилась воле господина хозяина на Руси; главным содержанием такой диктаторской воли являются репрессии, персональные экзекуции, тотальный контроль, стремление всех и вся взять под полицейский контроль. Она постоянно спекулирует, манипулирует слабостями работников и на этой основе доводит их до состояния полного подчинения и послушания ${ }^{34}$, что на практике приводило $к$ безынициативности зависимых лиц (кабальных людей, работных людей, крестьян и иных лиц с аналогичным положением в общества), в том числе в вопросах личного обеспечения, в котором такие лица рассчитывали на экономически сильную сторону (государство, помещика, господина), по воле которых преимущественно было социально обеспечить лишь прожиточный минимум зависимых лиц.

Реальные механизмы защиты права на социальное обеспечение для всех нуждающихся лиц в дореволюционной России отсутствовали, в том числе и возможности судебной защиты такого права, которые получили законодательное закрепление лишь 1903 г. в Законе от 2 июня 1903 г. «О вознаграждении потерпевших вследствие несчастных случаев, а равно членов их семей на предприятиях фрабрично-заводской, горной и горнозаводской промышленности» ${ }^{35}$.

${ }^{33}$ Бедность в России приобрела значительные масштабы: по сведениям «Новой газеты», на 2019 г. 13,1 \% населения имеют доходы ниже прожиточного минимума, каждый четвертый ребенок живет в бедной семье, МРОТ и прожиточный минимум составляют всего лишь около 200 долларов, реальные доходы населения падают шестой год (Бедность как государственное преступление // Новая газета. 2019). URL: https://novayagazeta.ru/ (дата обращения: 02.08.2020).

${ }^{34}$ См.: Троценко О. С. Вопросы ответственности при формировании частноправовых начал в трудовых правоотношениях). URL: https://cyberlenika.ru/ (дата обращения: 02.08.2020) ; Мордачев В. Д. Теория обмена труда : в 5 кн. Кн. 4 : Правовая форма обмена. Екатеринбург, 2009. С. 98.

${ }^{35}$ Полн. собр. законов. Т. 23, № 23060. 


\section{Библиографический список}

Баринова Г. В. Должны служить пожизненным и тихим для раненых воинов пристанищем // Военно-исторический журнал. 2015. № 9.

Бедность как государственное преступление // Новая газета. 2019. URL: https://novayagazeta.ru/

Владимирский-Буданов М. Ф. Обзор истории русского права. СПб., 1886.

Владимирский-Буданов М. Ф. Обзор истории русского права. Ростов н/Д : Феникс, 1995.

Гаврилина Н. А. Роль земских учреждений в развитии общественного призрения во второй половине XIX века // Вестник Саратовского гос. социально-экономического ун-та. 2005. № 11.

Галай Ю. Г., Черных К. В. Нищенство и бродяжничество в дореволюционной России : законодательные и практические проблемы. Н. Новгород : Нижегородская правовая академия, 2012.

Георгиевский П. И. Призрение бедных и благотворительность. СПб. : Типография Морского Министерства в Главном Адмиралтействе,1894.

Годунский Ю. Откуда есть пошла благотворительность на Руси // Наука и жизнь. 2019. 3 марта.

Исаев И. А. История государства и права России : учебник. 2-е изд., перераб. и доп. М. : Юристь, 2001.

Лозовская Е. Г., Харинина Л. В. Благотворительная деятельность ведомства учреждений императрицы Марии Федоровны // Вестник ВолГУ. Серия 7. 2007. Вып. 6.

Максимов Е. Д. Приказы общественного призрения (в их прошлом и настоящем) // Трудовая помощь. 1901. № 9.

Мордачев В. Д. Теория обмена труда : в 5 кн. Кн. 4 : Правовая форма обмена. Екатеринбург : Ажур, 2009.

Павлова О. К. Политика общественного призрения и благотворительности в царствование Петра I. URL: https://philosophy.spbu.ru/

Преображенский B. О благотворительности. Красноярск : Типография Елисейского Губернского управления, 1898.

Слолович И. К. Русское монашество : возникновение. Развитие. Сущность (988-1917). М. : Церковно-научный центр «Православная энциклопедия», 1997.

Троценко О. С. Вопросы ответственности при формировании частноправовых начал в трудовых правоотношениях. URL: https://cyberlenika.ru/

Ширяева С. В. Генезис социальной помощи в России (с момента появления христианства до рубежа XVIII-XIX вв.). URL: https://cyberlenika.ru/

\section{References}

Barinova G. V. Should Serve as a Lifelong and Quiet haven for wounded Soldiers // Military-historical journal. 2015. № 9.

Poverty as a State Crime // Novaya Gazeta, 2019. URL: https://novayagazeta. $\mathrm{ru} /$

Vladimirsky-Budanov M. F. Review of the History of Russian Law. St. Petersburg, 1886.

Vladimirsky-Budanov M. F. Review of the History of Russian Law. Rostovon-Don. Publishing house «Phoenix», 1995. 
Gavrilina N. A. The Role of Zemstvo Institutions in the Development of Public Charity in the Second Half of the XIX Century // Bulletin of the Saratov State Socio-Economic University. 2005. № 11.

Galay Yu. G., Chernykh K. V. Beggary and Vagrancy in Pre-revolutionary Russia: Legislative and Practical Problems. N. Novgorod: Nizhny Novgorod Law Academy, 2012.

Georgievsky P. I. Philanthropy for the Poor and Charity. St. Petersburg: Printing House of the Maritime Ministry in the Main Admiralty, 1894.

Godunsky Yu. Charity in Russia - where is it from // Nauka i Zhizn. March 3, 2019.

Isaev I. A. History of the State and Law of Russia: Textbook-2nd ed., Reprint. M.: Yurist, 2001.

Lozovskaya E. G., Kharinina L. V. Charitable Activity of the Department of Institutions of the Empress Maria Feodorovna // Bulletin of the Volga State University. Series 7. Issue 6. 2007.

Maksimov E. D. Orders of Public Charity (in their past and present) // Trudovaya Pomoshch. 1901. № 9.

Mordachev V. D. Theory of Labor Exchange in 5 Books. Book 4. The Legal Form of Exchange. Yekaterinburg: «Azhur», 2009.

Pavlova O. K. Politics of Public Charity and Philanthropy in the Reign of Peter I. URL: https://philosophy.spbu.ru/

Preobrazhensky V. About Charity. Krasnoyarsk: Printing House of the Elysian Provincial Administration, 1898.

Smolovich I. K. Russian Monasticism: the Emergence. Development. Essence (988-1917). Moscow: Church-scientific Center «Orthodox Encyclopedia», 1997.

Trotsenko O. S. Questions of Responsibility in the Formation of Private Law Principles in Labor Relations. URL: https://cyberlenika.ru/

Shiryaeva S. V. Genesis of Social Assistance in Russia (from the beginning of Christianity to the turn of the XVIII-XIX centuries). URL: https://cyberlenika.ru/

\section{Для цитирования:}

Гусев А. Ю., Яхина М. Р. Дореволюционный период развития социальной защиты в России (XVI-XVIII вв.) // Вестник Воронежского государственного университета. Серия: Право. 2021. № 3 (46). C. 72-87. DOI: https://doi.org/10.17308/vsu.proc. law.2021.3/3541

\section{Recommended citation:}

Gusev A.Yu., Yakhina M. R. Pre-revolutionary period of development of social protection in Russia (XVI-XVIII centuries) // Proceedings of Voronezh State University. Series: Law. 2021. № 3 (46). P. 72-87. DOI: https://doi.org/10.17308/vsu.proc.law.2021.3/3541

Национальный исследовательский университет "Высшая школа эконолики"

Гусев А. Ю., кандидат юридических наук, доцент Департалента теории права и межотраслевых юридических дисииплин фбакультета права, судья Ростовского районного суда Ярославской области

E-mail:agusev@hse.ru
National Research University "Higher School of Economics"

Gusev A. Yu., Candidate of Legal Sciences, Associate Professor of the Department of Theory of Law and Intersectoral Legal Disciplines, Faculty of Law, Judge of the Rostov District Court of the Yaroslavl Region

E-mail: E-mail: agusev@hse.ru 
Яхина М. Р., кандидат юридических наук, доцент Департалента систел судопроизводств и уголовного права фбакультета права

E-mail: MYakhina@hse.ru
Yakhina M. R., Candidate of Legal Sciences, Associate Professor of the Department of Judicial System and Criminal Law, Faculty of Law

E-mail:MYakhina@hse.ru 